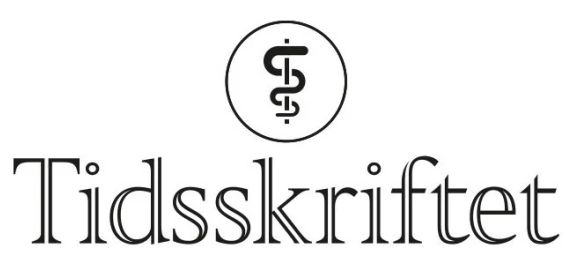

DEN NORSKE LEGEFORENING

\title{
Covid-19: Evidens-, eminens-, eller erfaringsbasert behandling?
}

KOMMENTAR

JON HENRIK LAAKE

jlaake@ous-hf.no

Jon Henrik Laake er overlege ved Oslo universitetssykehus, Rikshospitalet.

TOR AKSEL AASMUNDSTAD

TRINE KÅSINE

SØREN ERIK PISCHKE

ANDREAS BARRATT-DUE

Ingen av forfatterne har oppgitt noen interessekonflikter.

Gundem og medarbeidere gir her en god illustrasjon på hvorfor man ikke bør basere anbefalinger om behandlingsvalg på små observasjonsstudier (1). Av 26 pasienter ble 11 behandlet med respirator og 15 med oksygen og/eller non-invasiv ventilasjon (NIV). Fire fikk ikke tilbud om respiratorbehandling. Disse er tatt ut av den videre analysen. Av de resterende 22 døde 2 pasienter. Dette gir en dødelighet på 9 prosent. Et meget godt resultat. Behandlingsbegrensninger er vanlige i intensivavdelinger, og mange regner dette som en forutsetning for å kunne drive etisk forsvarlig intensivmedisin (2 2 . Det er derfor gledelig at våre kollegaer opplyser leserne om dette. Men det er vanlig å inkludere disse pasientene i observasjonsstudier der død er endepunktet. Dersom vi forutsetter at de fire pasientene som ikke ble inkludert overlevde intensivoppholdet blir dødeligheten 7,7\%, og dersom de døde $23 \%$. Dersom de døde, og regnes med i gruppen som kun fikk oksygen eller NIV, blir dødeligheten i denne gruppen $26 \%$. Slik kan vi fortsette.

Forfatterne konkluderer «at man i mange tilfeller, selv med betydelig hypoksemi, kan


high flow gir tilfredsstillende klinisk bedring og pasienten ikke er utmattet». Forbeholdene er mange. 
Forfatterne omtaler internasjonale evidensbaserte retningslinjer for behandling av pasienter med alvorlig lungesviktsyndrom (ARDS) som «internasjonale erfaringer» (3). På denne måten visker de ut skillet mellom egen synsing og anbefalinger som bygger på randomiserte studier. Forfatterne støtter seg på synspunkter som tidlig i pandemien ble fremsatt av en av intensivmedisinens berømtheter, Luciano Gattinoni, og medarbeidere, og som senere er blitt kraftig imøtegått (4). Sen erkjennelse av at pasienter har ARDS er assosiert med forsinket etterlevelse av evidensbaserte anbefalinger og høyere dødelighet (5).

Dødeligheten til kritisk syke Covid-19-pasienter er lav i Norge, lavere enn mange fryktet, og lavere enn i mange andre land. Vi er enige med forfatterne $i$ at innsatsen fra intensivsykepleierne er en nøkkelfaktor bak suksessen. Men vi tror og håper at respekt for internasjonale evidensbaserte retningslinjer også har spilt en viktig rolle.

\section{LITTERATUR}

1. Gundem T, Olasveengen TM, Hovda KE et al. Ventilasjonsstøtte for hypoksemiske intensivpasienter med covid-19. Tidsskr Nor Legeforen 2020; 140. doi: 10.4045/tidsskr.20.0445. [CrossRef]

2. Sprung CL, Ricou B, Hartog CS et al. Changes in End-of-Life Practices in European Intensive Care Units From 1999 to 2016. JAMA 2019;322: 1-12. [PubMed][CrossRef]

3. Scandinavian Society of Anaesthesiology and Intensive Care Medicine. Scandinavian clinical practice guideline on mechanical ventilation in adults with the acute respiratory distress syndrome. Acta Anaesthesiol Scand 2015; 59: 286-97. [PubMed][CrossRef]

4. Fan E, Beitler JR, Brochard L et al. COVID-19-associated acute respiratory distress syndrome: is a different approach to management warranted? Lancet Respir Med 2020; 8: 816-21. [PubMed] [CrossRef]

5. Needham DM, Yang T, Dinglas VD et al. Timing of low tidal volume ventilation and intensive care unit mortality in acute respiratory distress syndrome. A prospective cohort study. Am J Respir Crit Care Med 2015; 191: 177-85. [PubMed][CrossRef]

Publisert: 7. september 2020. Tidsskr Nor Legeforen. DOI: 10.4045/tidsskr.20.o649

(C) Tidsskrift for Den norske legeforening 2023. Lastet ned fra tidsskriftet.no 26. april 2023. 